\title{
IMPLEMENTASI FUZZY INFERENCE SYSTEM METODE TSUKAMOTO PADA PENGAMBILAN KEPUTUSAN PEMBERIAN KREDIT PEMILIKAN RUMAH
}

\author{
Wilis Kaswidjanti $^{1)}$, Agus Sasmito Aribowo ${ }^{2)}$, Cahyo Budi Wicaksono ${ }^{3)}$ \\ 1,2,3) Prodi Teknik Informatika UPN "Veteran" Yogyakarta \\ Jl. Babarsari 2 Tambakbayan 55281 Telp (0274) 485323 \\ email : wilisk@upnyk.ac.id
}

\begin{abstract}
Abstrak
Competition in today's banking world is getting heavier and tighter. This is because the products of the bank with the other banks can be said to be the same. So the competition for good customers to obtain product deposits and loans (mortgages) increasingly difficult. But the banking world are now widely utilize information technology to banking activities. One of the use of information technology is the use of decision support applications for granting loans (mortgages). The method used in the decision support system is a Fuzzy Inference System (FIS) to determine the calculation method of Tsukamoto decision. The implementation of this application is more emphasis on the decision-making process for granting to produce a decision issued.
\end{abstract}

Keywords: Decision Support Systems, Home Ownership Credit (KPR), Fuzzy Inference System (FIS) Tsukamoto method

Persaingan di dunia perbankan saat ini semakin berat dan ketat. Hal ini disebabkan karena produk satu bank dengan bank yang lainnya bisa dikatakan sama. Sehingga persaingan untuk medapatkan nasabah baik untuk produk dana simpanan dan Kredit Pemilikan Rumah (KPR) semakin sulit. Tetapi dunia perbankan saat ini sudah banyak memanfaatkan teknologi informasi untuk kegiatan perbankannya. Salah satu pemanfaatan teknologi informasi adalah penggunaan aplikasi pendukung keputusan untuk pemberian Kredit Pemilikan Rumah (KPR). Metode yang digunakan dalam sistem pendukung keputusan ini adalah Fuzzy Inference System (FIS) metode tsukamoto untuk menentukan perhitungan pengambilan keputusan. Implementasi dari aplikasi ini lebih ditekankan pada proses pengambilan keputusan untuk pemberian sampai menghasilkan sebuah keputusan yang dikeluarkan.

Kata Kunci : Sistem Pendukung Keputusan, Kredit Pemilikan Rumah (KPR), Fuzzy Inference System (FIS) Metode Tsukamoto.

\section{PENDAHULUAN}

Pada saat ini kebutuhan akan tempat tinggal meningkat pesat sehingga kredit kepemilikan rumah (KPR) mengalami perkembangan, hal ini dapat dilihat dengan banyaknya bank-bank di Indonesia yang menawarkan KPR dengan berbagai penawaran dengan syarat dan ketentuan yang berbeda-beda. Perkembangan KPR yang semakin kompleks maka diperlukan sistem komputerisasi untuk membantu para calon debitur mengetahui kelayakan dalam pengambilan KPR. Aplikasi sistem pendukung keputusan pada saat ini telah berkembang, dengan menerapkan metode-metode seperti fuzzy inference system (FIS) metode Tsukamoto. Metode ini banyak dimanfaatkan oleh berbagai bidang tak terkecuali pada bidang perekonomian. Berdasarkan kebutuhan yang dijelaskan di atas maka dirancang aplikasi pendukung keputusan KPR yang dapat membantu calon debitur utuk mengetahui kelayakan dalam mendapatkan kredit sehingga calon debitur dapan mengatur keuangannya sebelum mengambil KPR. Tujuan penelitian ini adalah menghasilkan mengimplementasikan FIS metode Tsukamoto pada pengambilan keputusan KPR yang dapat meningkatkan efektifitas maupun efisiensi waktu. Hasil yang diharapkan adalah untuk mempermudah calon debitur dalam mengajukan permohonan KPR, membantu calon debitur untuk mengatur keuangan sebelum mengajukan permohonan KPR dan membantu pihak bank/pengembang perumahan dalam pemasaran. 


\section{TINJAUAN PUSTAKA}

Penelitian yang menggunakan sistem pakar telah dilakukan, antara lain: Arkham Zahri Rakhman,dkk. (2012) berjudul Fuzzy Inference System Dengan Metode Tsukamoto Sebagai Pemberi Saran Pemilihan Konsentrasi (Studi Kasus: Jurusan Teknik Informatika UII). Penelitian-penelitian tersebut diatas, tidak sama dengan penelitian yang dibuat yaitu Implementasi Fuzzy Inference System Metode Tsukamoto Pada Pengambilan Keputusan Pemberian Kredit Pemilikan Rumah. Tapi secara umum aspek-aspek yang diperoleh penelitipeneliti terdahulu memberi dukungan informasi yang diperlukan.

\subsection{Logika Fuzzy}

Konsep logika fuzzy pertama kali diperkenalkan oleh professor Lotfi A. Zadeh dari Universitas California, pada bulan Juni 1965. Logika fuzzy merupakan generalisasi dari logika klasik yang hanya memiliki dua nilai keanggotaan yaitu 0 dan 1. Dalam logika fuzzy, nilai kebenaran suatu pernyataan berkisar dari sepenuhnya benar sampai dengan sepenuhnya salah. Dengan teori himpunan fuzzy, suatu objek dapat menjadi anggota dari banyak himpunan dengan derajat keanggotaan yang berbeda dalam masing-masing himpunan. Konsep ini berbeda dengan teori himpunan biner (crisp). Teori himpunan biner tergantung pada logika duanilai (two-valued logic) untuk menentukan apakah sebuah objek merupakan suatu anggota himpunan atau bukan (Klir \& Bo,1995).

\subsection{Himpunan Fuzzy}

Himpunan fuzzy memiliki 2 atribut, yaitu (Kusumadewi,2004):

a. Linguistik, penamaan suatu grup yang mewakili suatu keadaan atau kondisi tertentu dengan menggunakan bahasa alami, seperti: dingin,sejuk,normal,hangat,panas.

b. Numeris, suatu nilai (angka) yang menunjukkan ukuran dari suatu variabel, seperti: 0, 1, 2, 3,4 , dst.

Ada beberapa hal yang perlu diketahui dalam memahami sistem fuzzy, yaitu : variabel fuzzy, himpunan fuzzy, semesta pembicaraan, dan domain.

\subsection{Fungsi Keanggotaan}

Fungsi keanggotaan (membership function) adalah suatu kurva yang menunjukkan pemetaan titik-titik input data ke dalam nilai keanggotaannya yang memiliki interval antara 0 sampai 1 (Kusumadewi,2004).

\subsection{Sistem Infrensi Fuzzy Tsukamoto}

Pada Metode Tsukamoto, setiap konsekuen pada aturan yang berbentuk IF-Then harus direpresentasikan dengan suatu himpunan fuzzy dengan fungsi keanggotaan yang monoton. Sebagai hasilnya, output hasil inferensi dari tiap-tiap aturan diberikan secara tegas (crisp) berdasarkan $\alpha$ - predikat (fire strength). Hasil akhirnya diperoleh dengan menggunakan rata-rata terbobot (Kusumadewi, 2004). Berikut gambar inferensi dengan menggunakan Metode Tsukamoto Gambar 1.

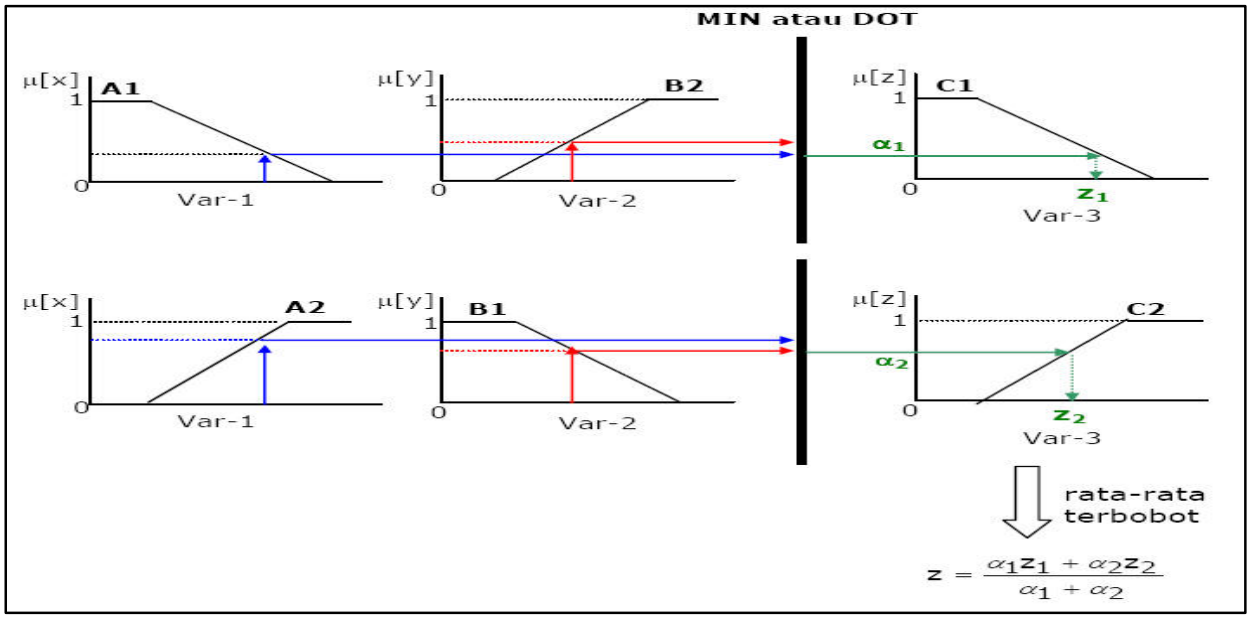

Gambar 1 Fungsi Keanggotaan linear naik 


\section{METODE PENELITIAN}

Metodologi yang digunakan adalah metode Waterfall. Metode pengembangan sistem sekuensial linier atau yang sering disebut juga dengan siklus kehidupan klasik atau model air terjun (waterfall model) memberikan sebuah pendekatan pengembangan sistem yang sistematik dan sekuensial, dimulai dari fase perencanaan sistem, analisis, desain, kode, pengujian, dan pemeliharaan (Pressman,2002). Model ini adalah model klasik yang bersifat sistematis, berurutan dalam membangun software.Tahapan-tahapan dari metode Waterfall adalah sebagai berikut: Requirements Analysis and Definition, System and Software Design, Implementation and Unit Testing, Integration and System Testing, dan Operation and Maintenance.

\subsection{Perancangan Sistem}

Pada perancangan proses ini terdapat Data Flow Diagram (DFD) dan Entity Relationship Diagram (ERD). Berikut DFD level 1 sistem pendukung keputusan KPR pada gambar 2. Berikut merupakan ERD sistem pendukung keputusan KPR pada gambar 3.

\subsection{Rancangan Model Logika Fuzzy}

Model yang dipaki dalam perancangan sistem pengambilan keputusan ini adalah model logika fuzzy. Berikut merupakan diagram penentuan sistem logika fuzzy tsukamoto pada gambar 4.

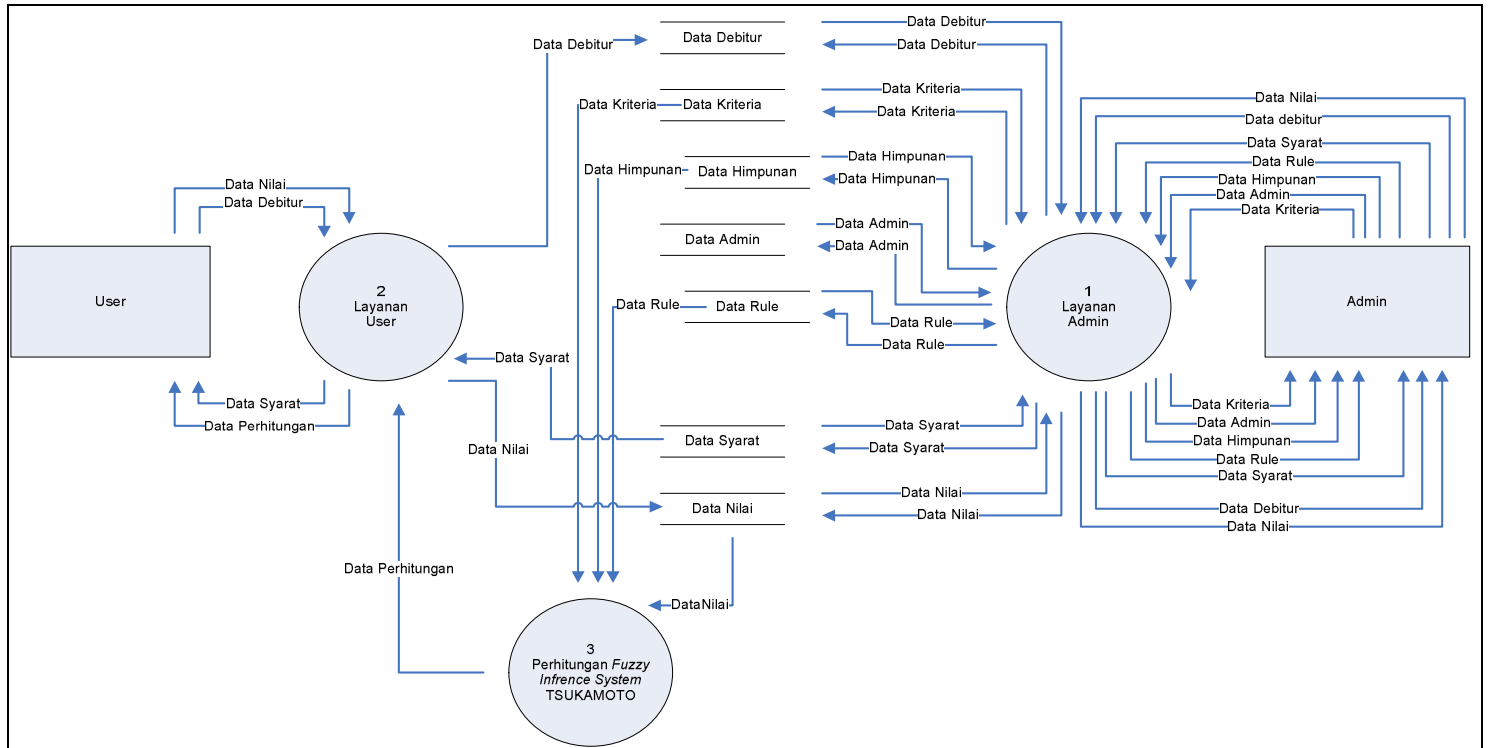

Gambar 2 DFD level 1 sistem pendukung keputusan KPR

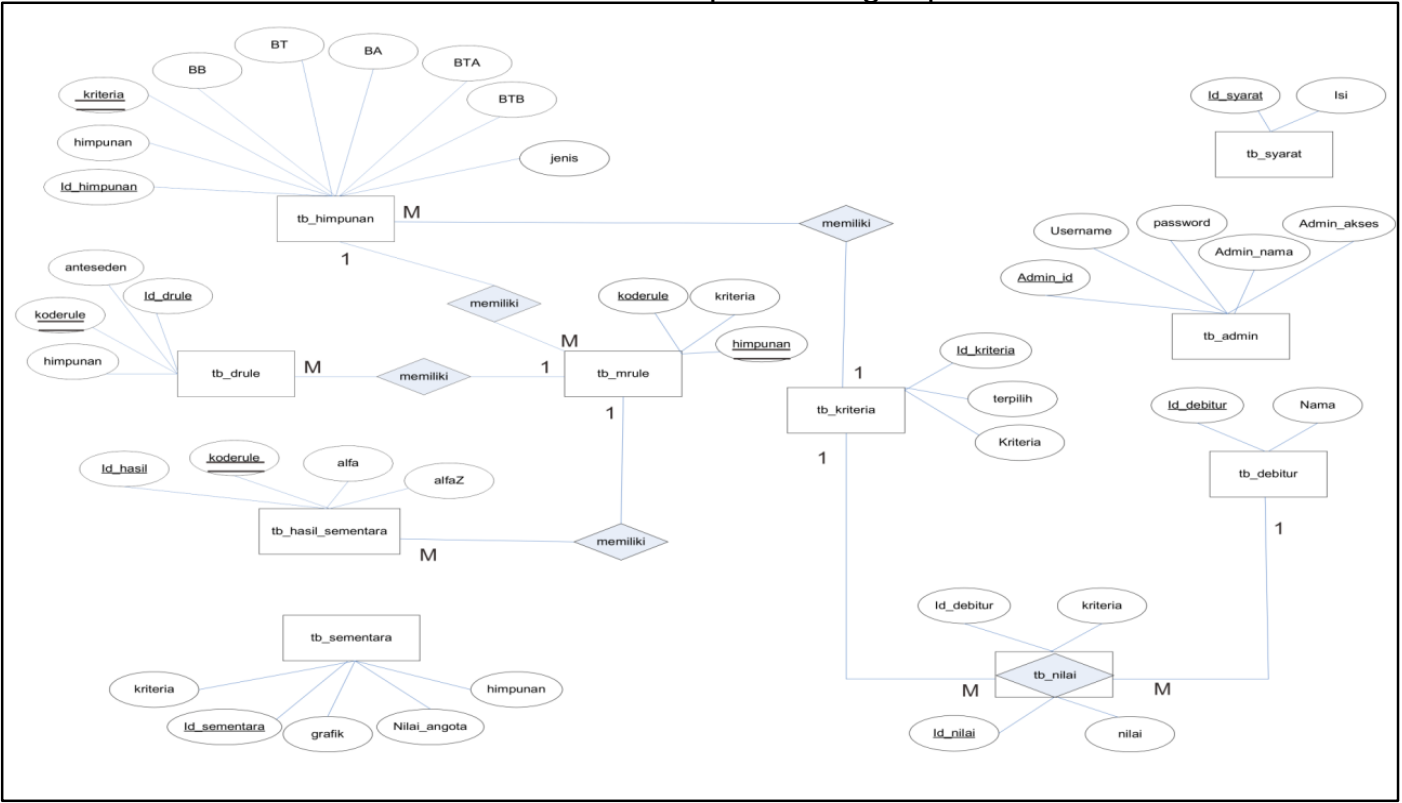


Gambar 3 Entity Relationship Diagram (ERD)

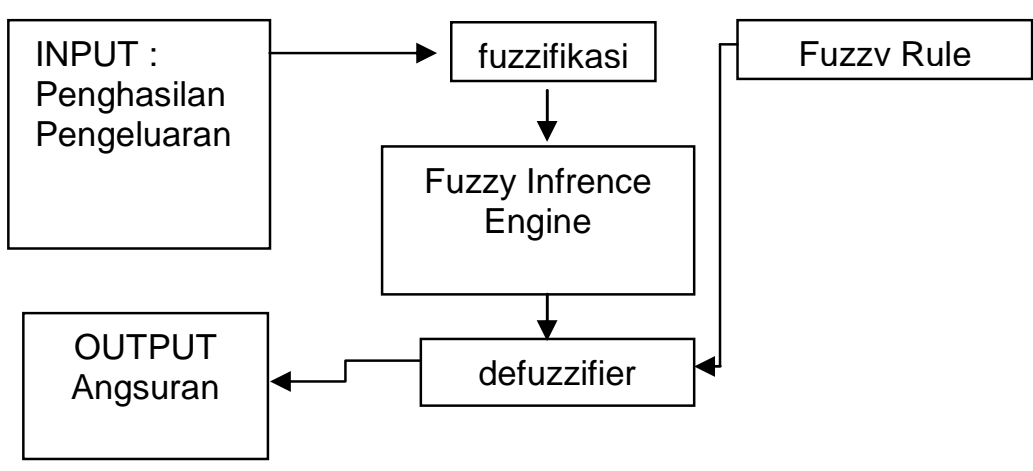

Gambar 4 Diagram Penentuan Sistem Logika Fuzzy Tsukamoto

\subsubsection{Himpunan Fuzzy}

Proses pembentukan himpunan fuzzy ini digunakan untuk menghitung nilai keanggotaan yang terdiri dari beberapa masukan yaitu variabel-variabel yang mempengaruhi perhitungan. Adapun komposisi penilaian yang digunakan adalah :

1. Variabel Input PENGHASILAN

Variabel penghasilan merupakann variabel pendapatan / gaji/ penghasilan calon dibitur yang akan mengambil KPR. Variable penghasilan dibagi menjadi 3 himpunan fuzzy yaitu: Rendah (R), Sedang(S), Tinggi(T). Himpunan Rendah dan Tinggi megunakan kurva linier rendah dan tinggi, sedangkan himpunan Sedang menggunakan kurva bentuk segitiga.

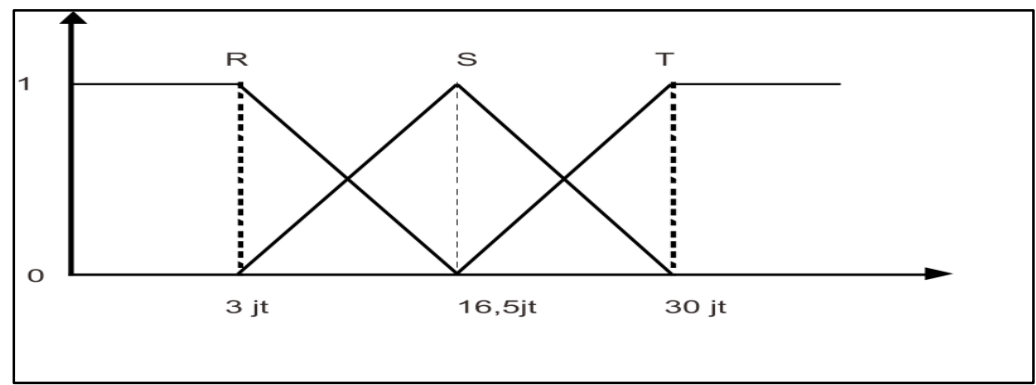

Gambar 5 Representasi Variabel PENGHASILAN

a. Dengan fungsi keanggotaan :

$$
\begin{aligned}
& \mu R(x=\text { PENGHASILAN })\left\{\begin{array}{cl}
1 & : j i k a \ldots x \leq 3 j t \\
x-3 j t & : 3 j t<j i k a \ldots x<30 j t \\
0 & ; j i k a \ldots x \geq 30 j t
\end{array}\right. \\
& \mu S(x=\text { PENGHASILAN })\left\{\begin{array}{cl}
0 & : j i k a \ldots x \geq 16,5 j t \\
(x-3 j t) /(16,5 j t-3 j t) & : j i k a 3 j t<x<16.5 j t \ldots .(2) \\
(30 j t-x) /(30 j t-16,5 j t) & : j k k a 16,5 j t<x<30 j t
\end{array}\right. \\
& \mu T(x=\text { PENGHASILAN })\left\{\begin{array}{cl}
0 & : j i k a \ldots x \leq 3 j t \\
30 j t-x & \vdots j i k a 3 j t<x<30 j t \\
1 & : j \text { jika } x \geq 30 j t
\end{array}\right.
\end{aligned}
$$

b. Nilai Keanggotaan PENGHASILAN

$$
\begin{aligned}
& \mu \text { Rendah }[5 j t]=\frac{(5 j t-3 j t)}{(30 j t-3 j t)}=0,07 \\
& \mu \text { Sedang }[5 j t]=\frac{(5 j t-3 j t)}{(30 j t-3 j t)}=0,07 \\
& \mu \text { Tinggi[5jt] }=\frac{(30 j t-5 j t)}{(30 j t-3 j t)}=0,92
\end{aligned}
$$

2. Variabel Input PENGELUARAN 
Variabel pengeluaran merupakann variabel angsuran lain / pengeluaran calon dibitur yang akan mengambil KPR. Variabel penghasilan dibagi menjadi 3 himpunan fuzzy yaitu: Rendah $(R)$, Sedang(S), Tinggi(T). Himpunan Rendah dan Tinggi megunakan kurva linier rendah dan tinggi, sedangkan himpunan Sedang mengunakan kurva bentuk segitiga.

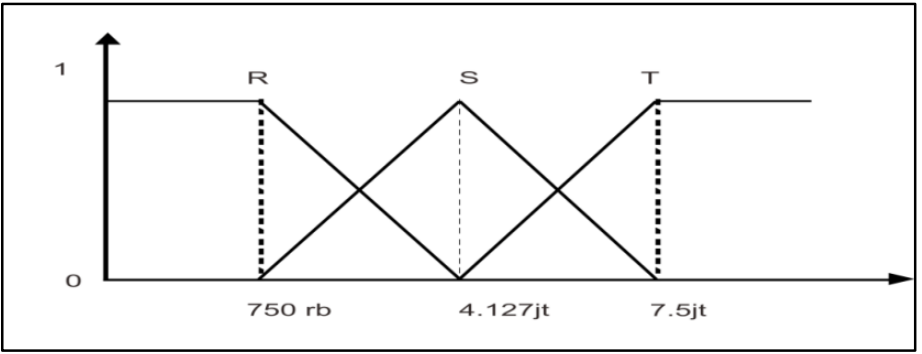

Gambar 6 Representasi Variabel PENGELUARAN

a. Dengan fungsi keanggotaan :

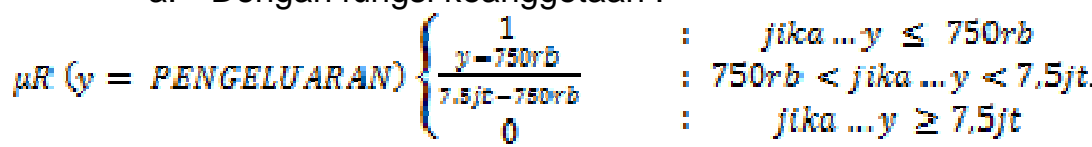

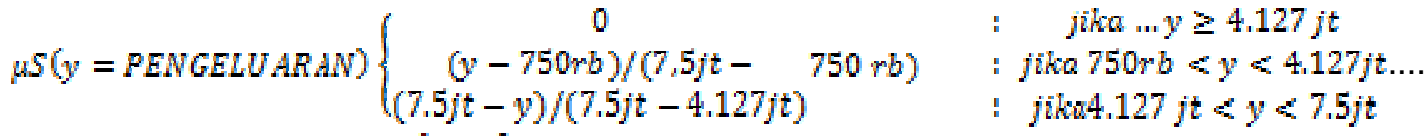

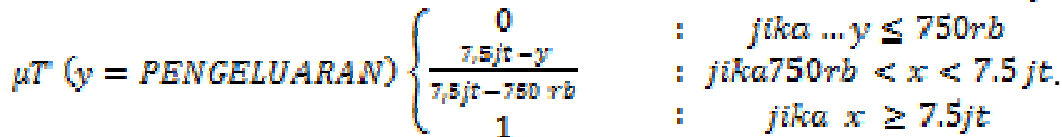

b. Nilai Keanggotaan PENGELUARAN

$$
\begin{aligned}
& \mu \text { Rendah }[3 j t]=\frac{(3 j t-750 \mathrm{rb})}{(7,5 j t-750 \mathrm{rb})}=0.33 \\
& \mu \text { Sedang }[3 j t]=\frac{(3 j t-750 \mathrm{rb})}{(7,5 j t-750 \mathrm{rb})}=0.33 \\
& \mu \text { Tinggi }[3 j t]=\frac{(7,5 j t-3 j \mathrm{t})}{(7,5 j t-750 \mathrm{rb})}=0,66
\end{aligned}
$$

3. Variabel Input ANGSURAN

Variabel angsuran merupakann variabel cicilan/ansuran yang harus dibayar oleh calon dibitur yang akan mengambil KPR. Variabel angsuran dibagi menjadi 3 himpunan fuzzy yaitu: Rendah $(\mathrm{R})$, Sedang(S), Tinggi(T). Himpunan Rendah dan Tinggi megunakan kurva linier rendah dan tinggi, sedangkan himpunan Sedang mengunakan kurva bentuk segitiga.

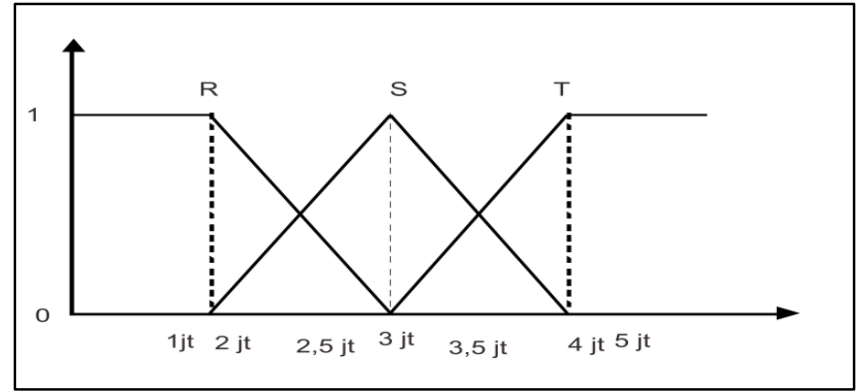

Gambar 7 Repersentasi Variabel ANGSURAN

a. Dengan funsi keanggotaan :

$$
\mu R\left(z = \text { ANGSURAN } \left\{\begin{array}{cl}
1 & \text { : } j i k a \ldots z \leq 1 j t \\
\frac{2,5 j-z}{2,5 j t-1 j t} & : 1 j t<j k a \ldots z<2,5 j t . \\
0 & \text { ikka } \ldots z \geq 2,5 j t
\end{array}\right.\right.
$$




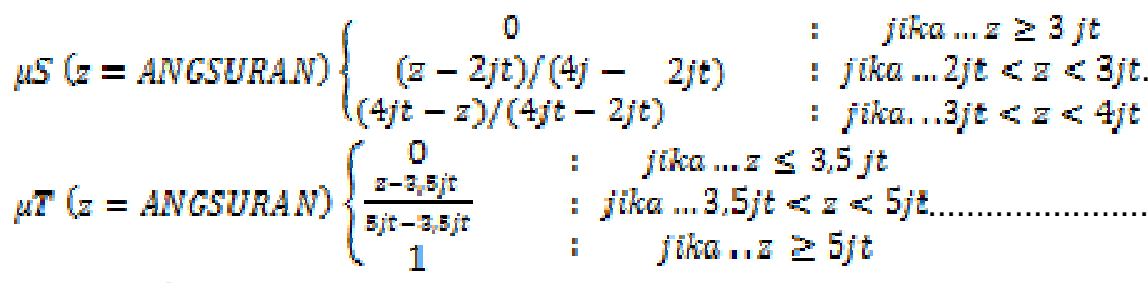

\subsubsection{Basis Aturan}

Penentuan basis aturan fuzzy bergantung pada variabel inputan. Ketiga variabel masukan jika dikombinasikan akan membentuk 27 buah aturan. Basis aturan yang dihasilkan tabel aturan (Tabel 1).

Tabel 1 Basis aturan fuzzy

\begin{tabular}{|c|c|c|c|c|c|}
\hline \multirow{2}{*}{ No } & \multirow{11}{*}{ IF } & \multicolumn{2}{|c|}{ VARIABEL INPUT } & \multirow{11}{*}{ THEN } & VAEIABEL INPUT \\
\hline & & PENGHASILAN & PENGELUARAN & & ANGSURAN \\
\hline 1 & & Tinggi & Tinggi & & Rendah \\
\hline 2 & & Tinggi & Sedang & & Sedang \\
\hline 3 & & Tinggi & Rendah & & Tinggi \\
\hline 4 & & Sedang & Tinggi & & Rendah \\
\hline 5 & & Sedang & Sedang & & Rendah \\
\hline 6 & & Sedang & Rendah & & Rendah \\
\hline 7 & & Rendah & Tinggi & & Rendah \\
\hline 8 & & Rendah & Sedang & & Rendah \\
\hline 9 & & Rendah & Rendah & & Rendah \\
\hline
\end{tabular}

\subsubsection{Inferensi Berdasarkan $\alpha$ - Predikat}

Nilai ANGSURAN yang dicari untuk setiap aturan menggunakan fungsi MIN pada aplikasi fungsi implikasi :

[1] IF Penghasilan Tinggi AND Pengeluaran Tinggi THEN Angsuran Rendah

$$
\begin{aligned}
& \alpha \text {-Predikat1 }=\mu \text { PenghasilanTinggi } \cap \text { pPengeluaranTinggi } \\
& =\min (\mu \text { PenghasilanTingg } i[5 j t] \text {, } \mu \text { PengeluaranTingg } i[3 j t] \text { ) } \\
& =\min (0,07,0,33) \\
& =0,07
\end{aligned}
$$

Himpunan Angsuran Rendah,

$$
\begin{aligned}
Z_{1} & =0,07 *(10 j t-1 j t)+1 j t \\
& =2388888,80
\end{aligned}
$$

[2] IF Penghasilan Tinggi AND Pengeluaran Sedang THEN Angsuran Sedang

$$
\begin{aligned}
& \alpha-\text { Predikat } 2=\mu \text { PenghasilanTinggi } \cap \mu \text { PengeluaranSedang } \\
& =\min (\mu \text { PenghasilanTinggi }[5 j], \mu \text { PengeluaranSedang }[3 j t]) \\
& =\min (0,07,0,33) \\
& =0,07
\end{aligned}
$$

Himpunan Angsuran Sedang,

$$
\begin{aligned}
& Z_{2}=(10 j t+1 j t) / 2 \\
& =3000000
\end{aligned}
$$

[3] IF Penghasilan Tinggi AND Pengeluaran Rendah THEN Angsuran Tinggi

$$
\begin{aligned}
& \alpha-\text { Predikat } 3=\mu \text { PenghasilanTinggi } \cap \mu \text { PengeluaranRendah } \\
& =\min (\mu \text { PenghasilanT ing } i[5 j t], \mu \text { PengeluaranRendah }[3 j t] \\
& =\min (0,07,0,66) \\
& =0,07
\end{aligned}
$$

Himpunan Angsuran Tinggi,

$$
\begin{aligned}
Z_{3} & =10 j t-(10 j t-1 j t) \div 0,07 \\
& =3611111,11
\end{aligned}
$$

[4] IF Penghasilan Sedang AND Pengeluaran Tinggi THEN Angsuran Rendah 
$\alpha-$ Predikat $4=\mu$ PenghasilanSedang $\cap \mu$ PengeluaranTinggi

$=$ min ( $\mu$ Penghasilansedang $[5 \mathrm{jt}]$, $\mu$ PengeluaranThggi $[3 \mathrm{jt}]$ )

$=\min (0,07,0,33)$

$=0,07$

Himpunan Angsuran Rendah,

$$
\begin{aligned}
Z_{4}= & 0,07 *(10 j t-1 j t)+1 j t \\
& =2388888,88
\end{aligned}
$$

[5] IF Penghasilan Sedang AND Pengeluaran Sedang THEN Angsuran Rendah

$\alpha-$ Predikat5 $=\mu$ Penghasilansedang $\mathrm{n} \mu$ Pengeluaransedang

$=\min$ ( $\mu$ Penghasilansedang [ 5jt], Pengeluaransedang [3jt])

$=\min (0,07,0,33)$

$=0,07$

Himpunan Angsuran Rendah,

$$
\begin{gathered}
Z_{5}=0,07 *(10 j t-1 j t)+1 j t \\
=2388088,88
\end{gathered}
$$

[6] IF Penghasilan Sedang AND Pengeluaran Rendah THEN Angsuran Rendah

$$
\begin{aligned}
& \alpha-\text { Predikat } 6=\mu \text { Penghasilansedang } \cap \mu \text { PengeluaranRendah } \\
& =\min (\mu \text { PenghasilanSedang }[5 \mathrm{jt}], \mu \text { PengeluaranRendah }[3 j \mathrm{t}]) \\
& =\min (0,07,0,66) \\
& =0,07
\end{aligned}
$$

Himpunan Angsuran Tinggi,

$$
\begin{aligned}
Z_{6}= & 0,07 *(10 j t-1 j t)+1 j t \\
& =2388888,88
\end{aligned}
$$

[7] IF Penghasilan Rendah AND Pengeluaran Tinggi THEN Angsuran Rendah

$\alpha-$ Predikat $7=\mu$ PenghasilanRendah $\cap \mu$ PengeluaranTinggi

$=\min$ ( $\mu$ PenghasilanTing $g i[5 j]$, $\mu$ PengeluaranTing $g i[3 j t]$ )

$=\min (0,92,0,33)$

$$
=0,33
$$

Himpunan Angsuran Rendah,

$$
\begin{aligned}
Z_{7}= & 0,07:(10 j t-1 j t)+1 j t \\
& =2000000
\end{aligned}
$$

[8] IF Penghasilan Rendah AND Pengeluaran Sedang THEN Angsuran Rendah

$$
\begin{aligned}
& \alpha-\text { Predikat8 }=\mu \text { PenghasilanRendah } \cap \mu \text { PengeluaranSedang } \\
& =\min (\mu \text { PenghasilanTing }[15 \mathrm{jt}], \mu \text { PengeluaranSedang }[30 j t]) \\
& =\min (0,95,0,33) \\
& =0,33
\end{aligned}
$$

Himpunan Angsuran Rendah,

$$
\begin{aligned}
Z_{8}= & 0,07 *(10 j t-1 j t)+1 j t \\
& =2000000
\end{aligned}
$$

[9] IF Penghasilan Rendah AND Pengeluaran Rendah THEN Angsuran Rendah

$\alpha$-Predikat9 $=\mu$ PenghasilanRendah $\cap \mu$ PengeluaranRendah

$=\min$ ( $\mu$ PenghasilanTinggi $[5 j t]$, pengeluaranTinggi $[3 j t]$ )

$=\min (0,95,0,66)$

$=0,66$

Himpunan Angsuran Rendah,

$$
\begin{aligned}
Z_{9}= & 0,66 *(10 j t-1 j t)+1 j t \\
& =15000000
\end{aligned}
$$




\subsubsection{Nilai Output}

$$
\begin{aligned}
Z & =\frac{\begin{array}{c}
\text { Berdasarkan rata-rata nilai terbobot, maka nilai } z \text { dapat dicari dengan cara berikut : } \\
\alpha \text { predikat } 1+\alpha \text { predikat } 2+\text { a predikat } 3+\ldots \ldots \ldots \text { predikat } 9
\end{array}}{(0,07 * 2388888,88)+(0,07 * 3000000)+(0,07 * 3611111,11)+\ldots \ldots(0,66 * 15000000)} \\
& =\frac{(0,07+07+0,07+0,07+\ldots \ldots 0,66}{} \\
& =1986111
\end{aligned}
$$

\section{HASIL DAN PEMBAHASAN}

Pada tahap selanjutnya adalah mengimplementasikan (menerapkan) sistem. Tahap ini ditampilkan antarmuka (interface) pada Aplikasi Fuzzy Inference System (FIZ) Metode Tsukamoto pada Pengambilan Keputusan Pemberian Kredit Pemilikan Rumah (KPR). Serta akan dijelaskan mengenai perangkat keras (hardware) dan perangkat lunak (software) yang digunakan dalam pembangunan Aplikasi FIS Metode Tsukamoto pada Pengambilan Keputusan KPR.

\subsection{Halaman Olah Data Himpunan SPK Tsukamoto Layanan Admin}

Halaman olah data himpunan SPK tsukamoto layanan admin merupan halaman yang digunakan untuk menambah, menghapus, menampilkan, dan mengubah data himpunan SPK tsukamoto pada layanan admin, dapat dilihat pada gambar 8 .

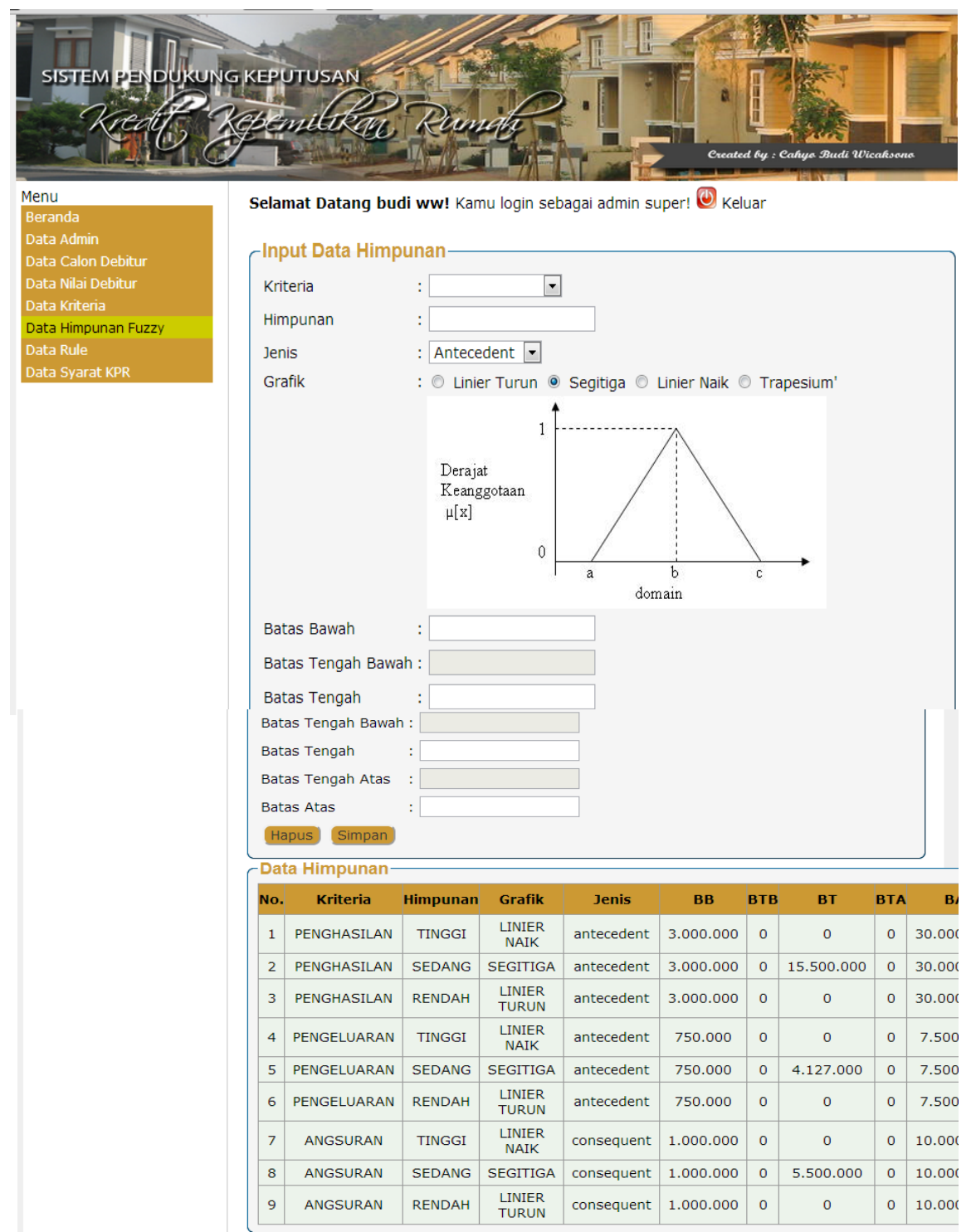


Gambar 10 Halaman Olah Data Himpunan SPK Tsukamoto Layanan Admin.

\subsection{Halaman Perhitungan KPR Layanan User}

Halaman perhitungan KPR layanan user merupakan halaman yang digunakan untuk melakukan perhitungan KPR. Dapat dilihat pada gambar 9.

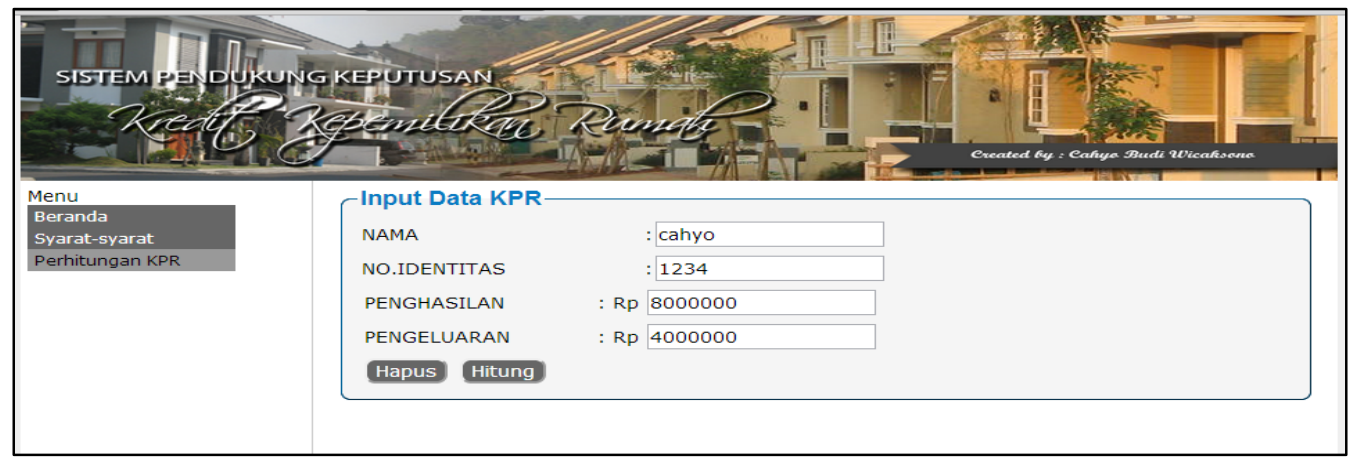

Gambar 9 Halaman Perhitungan KPR Layanan User.

\subsection{Halaman Hasil Perhitungan KPR Layanan User}

Halaman hasil perhitungan KPR layanan user merupan halaman yang digunakan untuk melihat hasil perhitungan KPR. Dapat dilihat pada gambar 10.

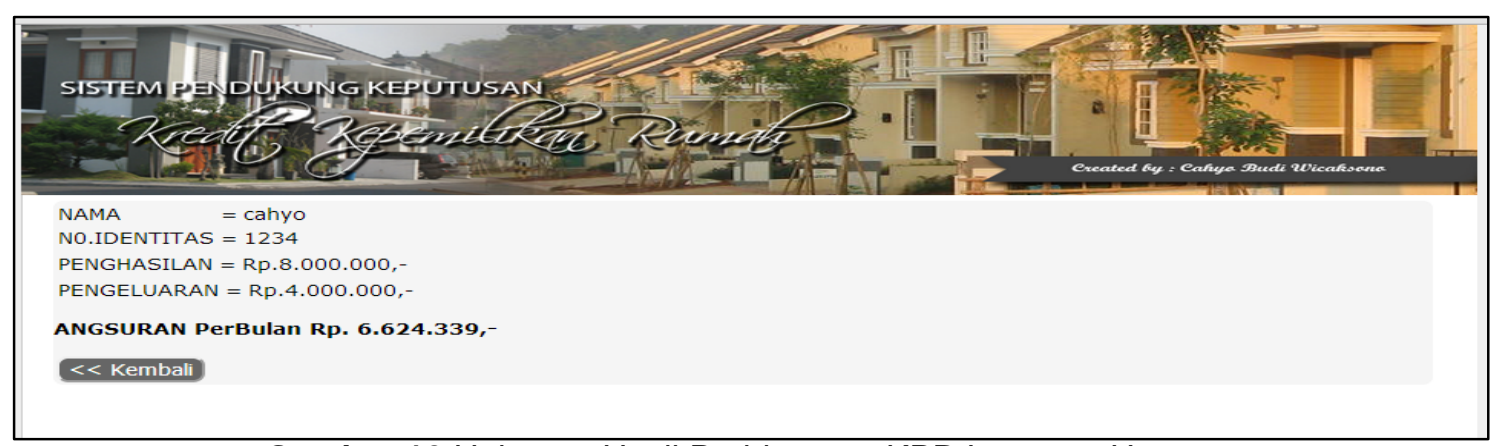

\footnotetext{
Gambar 10 Halaman Hasil Perhitungan KPR Layanan User.
}

\section{KESIMPULAN}

Dari penelitian yang telah dilakukan, dapat disimpulkan bahwa Fuzzy Infrence System (FIZ) Metode Tsukamoto dapat diimplementasikan pada Pengambilan Keputusan Pemberian Kredit Pemilikan Rumah (KPR). Kegunaan dari aplikasi ini adalah dapat membantu para calon debitur untuk menentukan kelayakan pengambilan KPR dan membantu pengembang perumahan/bank dalam pemasaran produknya. 


\section{DAFTAR PUSTAKA}

Hasan, M. Iqbal., 2004, Pokok-Pokok Materi Teori Pengambilan Keputusan, Ghalia Indonesia, Bogor Selatan.

Jogiyanto, H.M., 2001, Analisis dan desain sistem informasi, Penerbit Andi, Yogyakarta.

Kusumadewi, S, 2004, Aplikasi Logika Fuzzy untuk Pendukung Keputusan, Graha IImu, Yogyakarta.

Klir, G. J \& Y. Bo., 1995, Fuzzy Set and Fuzzy Logic: Theory and Applications. Prentice-Hall International, Inc, New Jersey.

Oetomo, Budi S.D., 2002, Perancangan dan Pembangunan Sistem Informasi, Penerbit Andi, Yogyakarta.

Pressman, S.R., 2002, Rekayasa Perangkat Lunak (Pendekatan Praktisi), Andi Ofset, Yogyakarta.

Rakhman, A.Z.,dkk., 2012, Fuzzy Inference System Dengan Metode Tsukamoto Sebagai Pemberi Saran Pemilihan Konsentrasi (Studi Kasus: Jurusan Teknik Informatika UII), Prosiding Seminar Nasional Aplikasi Teknologi Informasi 2012 (SNATI 2012), Yogyakarta.

Sommervile, lan., 2001, "Software Engineering". th $^{\text {th }}$ Addision Wesley. 